\title{
Influence of gibberellin inhibitors on the accumulation and redistribution of various forms of carbohydrates and nitrogen- containing compounds in plants of Solanum melongena $\mathrm{L}$.
}

Viktor Rogach ${ }^{1}$,

\author{
Kateryna Reshetnyk ${ }^{2 *}$, \\ Volodymyr Kuryata ${ }^{1}$,
}

\section{Tatyana Rogach ${ }^{1}$}

${ }^{1}$ Department of Biology,

Faculty of Natural Sciences and Geography, Vinnytsia Mykhailo Kotsuibynskyi

State Pedagogical University,

32 Ostrozkoho Street,

Vinnytsia, 21000, Ukraine

${ }^{2}$ Department of Botany and Ecology,

Faculty of Chemistry,

Biology and Biotechnologies,

Vasyl' Stus Donetsk National University,

600th-anniversary Street, 21,

Vinnytsia, 21021, Ukraine
The $0.025 \%$ tebuconazole (EW-250), $0.25 \%$ chlormequat chloride (CCC-750), and $0.15 \%$ ethephon (2-CEPA) influences growth processes, the leaf apparatus, chlorophyll concentration and various carbohydrates forms, and total nitrogen content in Solanum melongena $\mathrm{L}$. The decrease in the linear dimensions of the aubergine was established for all preparations. The most significant decrease in height was observed after the application of 2-HEPCs. The retardants increased the number of leaves, the dry matter mass of leaves, the leaf area, chlorophyll content, and the surface density of the leaf. EW-250 and CCC-750 retardants strengthened carbohydrate accumulation in aubergine fruits, mainly due to reducing forms. During the growing season, the total and protein nitrogen content decreased in roots and stems both in control and in experiment variants. EW-250 and CCC-750 accelerated total and protein nitrogen outflow from roots and stems and increased its content in leaves. Increasing the carbohydrates content in fruits the retardants simultaneously reduced the content of various nitrogen forms. Such changes in the dynamics of total nitrogen under the influence of tebuconazole led to enhanced fruit formation on each plant. Thus, retardants EW-250 and CCC-750 changed the nature of the donor-acceptor relations in them by increasing the outflow of plastic substances from vegetative organs to fruits and increasing the culture productivity.

Keywords: Solanum melongena L., antigibberellin preparations, leaf apparatus, sugars, starch, total nitrogen, productivity

*Corresponding author. Email: k.reshetnyk@donnu.edu.ua 


\section{INTRODUCTION}

The study into the regularities of the functioning of the donor-acceptor system of plants and the development of the means of exogenous regulation of the transfer of flows of assimilates and their orientation to economically important tissues and organs is an urgent task of modern phytophysiology. The application of retardants and ethyleneproducts makes it possible to change the tension of the donor-acceptor system of the plant due to the regulation of growth processes, photosynthesis, and redistribution of streams of plastic substances from the vegetative organs to the needs of carpogenesis (formation and growth of fruits), which ultimately optimizes the crop production process (Kuryat, Rogach, 2009; Singh et al., 2017; Shevchuk et al., 2018).

In particular, treatment with the triazolebased retardant paclobutrazole resulted in an increase in the area of the leaf surface in sweet potato plants and increased the content of reducing and non-reducing sugars in the leaves by $3.8 \%$. The preparation also increased the content of some amino acids and the productivity of the culture (Yooyongwech et al., 2017). The processing of mango plants with paclobutrazol increased the the crop yield and the content of all forms of sugars in fruits (Sarker et al., 2016). This same preparation increased the content of carbohydrates in rice plants (Xiang et al., 2017). The use of paclobutrazole in the budding phase of canola plants inhibited growth processes and increased the accumulation of soluble sugars, sucrose, and starch in stems and fruits while reducing their content in the roots. The retardant increased the efficiency of the utilization of carbohydrates by plants that had a positive effect on the crop yield (Hua et al., 2014). Soybean seeds were treated with uniconazole, another derivative of triazole. There was a decrease in the area of the leaf surface and increased productivity (Yan et al., 2015). The same retardant brought about an increase in the content of starch in plants of Landoltia punctata (Liu et al., 2014).
The application of the mixture of paclobutrazole and chlormequat chloride on a perennial ryegrass culture reduced the linear size of plants and increased the mass of raw and dry matter of the plant. Under the influence of a retardant mixture, the content of sugars increased and starch content decreased (Kasem, Abd El-Baset, 2015). Retardant chlormequat chloride and paclobutrazole increased sucrose content in lily leaves (Zheng et al., 2012). Other scientists found out that chlormequat chloride accelerated the outflow of soluble sugars from leaves to fruits in corn plants and increased the protein content in its leaves (Wang et al., 2016). This retardant increased the content of reducing sugars and starch in potato tubers (Koteswara Rao et al., 2017). The growth of the content of soluble sugars and amino acids under the influence of chlormequat chloride was also observed in ginkgo seedlings (Zhang et al., 2013). The use of cycocel on hemp plants has led to an increase in the content of reducing sugars in male plantlets compared with control variants (Sardoei et al., 2014). Cycocel also increased the total sugar content due to reducing forms of grapevine plants (Kumbar et al., 2017).

Photosynthetic productivity of plants during vegetation is considered the basis of the functioning of donor-acceptor relations in the depot system of assimilates - growth. It is known that in plants, the concept of donor-acceptor relations is determined by the system of direct and inverse relationships (Yu et al., 2015), where photosynthesis processes serve as the main donor, and the processes of growth and deposition of substances in the stock as acceptors of assimilates (Kiriziy et al., 2014).

Assimilates refer to different compounds that the plant assimilates during carbon photosynthesis, primarily transport and storage forms of carbohydrates, which are considered the basis of energy and metabolic processes, as well as "building material" in the processes of growth and development at all levels of the organization of a plant organism (Kiriziy et al., 2014). It is also known that stockpiling substances of various types play an important 
role in the buffer between photosynthesis as a "source" of assimilates, and the growth of the structural matter of vegetative, stock, and reproductive organs, as a "runoff" of assimilates, which to some extent determines the independence of growth processes from photosynthesis (Singh et al., 2017).

Carpogenesis is a powerful "attracting" centre in plant ontogenesis, the process of fruit growth and formation. It is also used as neoplasms due to photosynthesis, and is temporarily deposited in the vegetative organs - sugars and starch. The analysis of scientific data shows that when applying retardants in the process of vegetation, a large amount of carbohydrates is formed in the leaves of experimental plants that accumulate and form a powerful reserve of plastic compounds used to form a strong stem, to form more fruits, and to improve the quality of the crop yield.

The growth of crop yields under the influence of gibberellin inhibitors was noted in vegetables (Tkachuk, 2015; Rogach, Poprotska, Kuryata, 2016; Yooyongwech et al., 2017); fruiting (Sarker et al., 2016); oilseeds (Kuryata, Hodanic'ka, 2012; Kuryata, Polyvanyj, 2015; Kuryata, Poproc'ka, 2016; Sardoei et al., 2014), and leguminous (Golunova 2015; Yan et al., 2015) cultures.

However, scientific literature contains practically no data on the comparative effect of antigibberellin preparations with different mechanisms of action on the depositing activity of vegetative organs. Therefore, the purpose of our paper was to study the peculiarities of the accumulation and redistribution of various forms of carbohydrates and nitrogen during the vegetation period in the aubergine cv. "Almaz", under the action of tebuconazole, chlormequat chloride, and ethephon in connection with crop productivity.

\section{MATERIALS AND METHODS}

To study the influence of antigibberellin preparations of tebuconazole (EW-250), chlormequat chloride (CCC-750), and ethephon (2-chloroethyl phosphonic acid) on morphogenesis and productivity of the culture of aubergine cv. "Almaz", small-land field experiments were conducted in the plots of the agricultural farm "Barzhan P. G., in Gorbanivka village, Vynnitsia district, during the growing season of 2013-2015. Aubergine seeds were sown in greenhouses on 3 March 2013, 5 March 2014, and on 9 March 2015. The seedlings were planted on 22 May 2013, 29 May 2014, and on 12 May 2015 by a tape method with the formula $80+50+50 \times 25$. Mineral fertilizers $\mathrm{N}_{50} \mathrm{P}_{40} \mathrm{~K}_{30}$ were introduced. The area of the land was $33 \mathrm{~m}^{2}$, the repetition was fivefold.

The plants were sprayed in the morning with a paddle sprayer CO-12 "Marolex" until full wetting of leaves with a $0.25 \%$ solution of chlormequat chloride, $0.025 \%$ solution of tebuconazole and $0.15 \%$ solution of the ethephon into the budding phase 7 July 2013, 10 July 2014, and on 19 July 2015. The control plants were sprayed with water.

Phytometric indicators were determined on 15 plants. The content of sugars and starch was determined by the iodometric method, and the content of total nitrogen was determined by the Kjeldahl method. During the growing season, the content of the amount of chlorophylls in the fresh material was determined by spectrophotometric method on a spectrophotometer SF-16. The repeatability of biochemical studies was fivefold (AOAC, 2010). The text, tables, and graphs present the arithmetic mean and their standard errors. The results were statistically processed with Statistica 6.0 software package. One-factor dispersion analysis was used. Differences between the mean values were calculated by ANOVA, they were considered reliable at $P \leq 0.05$ (Van Emden, 2008).

\section{RESULTS}

The results of our research indicate that retardants tebuconazole and chlormequat chloride and ethylene producent ethephon cause changes in the anatomical and morphological and biochemical parameters of the aubergine cv. "Almaz". It was established that the preparations inhibited the linear growth of 
experimental plants. The most significant inhibition of plant growth was observed after the application of the ethephon. This preparation reduced the linear size of the plants by $27 \%$ (Table 1). Aubergine treatment with tebuconazole and chlormequat chloride shortened plant height by $15 \%$ and $14 \%$ respectively (Kuryata et al., 2016). Similar results under the influence of these drugs were also observed by other researchers (Golunova, 2015; Kuryata, Poprocka, 2016; Tkachuk, 2015).

The main place of assimilate synthesis, which spreads to all other organs and directly affects the content of carbohydrates in the vegetative and generative organs of plants, is the leaf.

Therefore, it is advisable to detect the changes in the quantitative parameters of the leaf apparatus as the triazole-based retardant tebuconazole caused their significant growth (Table 1).

Under the influence of this preparation, the number of leaves per plant increased by $16 \%$, and the mass of dry leaf matter by $31 \%$. Processing of aubergines with chlormequat chloride increased the number of leaves by $7 \%$, while the mass of dry leaf matter increased by $24 \%$ (Kuryata et al., 2016). Similar changes have also been documented by other scientists (Kuryata, Polyvanyj, 2015; Kuryata, Hodanic'ka, 2012). Ethylene producent ethephon significantly reduced both the amount and the mass of their dry matter (Kuryata, Kravets, 2016).
From the standpoint of photosynthetic activity, the index of the specific surface density of the leaves is essential, which shows the totality of structures providing photosynthesis and indirectly indicates the thickness of leaf blades. We found out that all gibberellin inhibitors increased it by $14-16 \%$ (Kuryata et al., 2016).

Gibberellin inhibitors, different in their mechanisms of action, influenced the area of leaves in different ways. Ethephon critically reduced this index, retardant tebuconazole increased significantly (22\%), and chlormequat chloride practically did not change it (Kuryata et al., 2016).

Given the changes in the quantitative indices of the leaf apparatus of aubergines after their treatment with growth regulators, we recommend to study the peculiarities of accumulation and redistribution of different forms of carbohydrates between plant organs in the ontogenesis process.

The analysis of the dynamics of sugars in the root indicates that during the vegetative season, there is an outflow of sugars from the underground vegetative organ, mainly due to reducing forms (Fig. 1). We found out that treatment with antigibberellin preparations contributed to the accumulation of sugars in the first half of the vegetation due to reducing forms and increased their outflow during carpogenesis. The highest amount of sugar was observed after treatment with tebuconazole.

Table 1. Influence of gibberellin inhibitors on growth processes of the aubergines of cv. "Almaz" (fruit ripening phase, average for 2013-2015, $n=15, \mathrm{x} \pm S D$ )

\begin{tabular}{c|c|c|c|c}
\hline Variant of the experiment & $\begin{array}{c}\text { Control } \\
\text { variant }\end{array}$ & 2-CEPA & EW-250 & CCC-750 \\
\hline Indicator & $54.57 \pm 2.68$ & $\star 39.68 \pm 1.89$ & ${ }^{\star} 46.43 \pm 2.21$ & ${ }^{\star} 47.09 \pm 2.28$ \\
\hline Plant height, cm & $88.67 \pm 3.32$ & ${ }^{*} 70.08 \pm 3.42$ & ${ }^{\star} 103.09 \pm 4.97$ & $95.17 \pm 4.71$ \\
\hline Number of leaves per plant, pcs. & $31.75 \pm 1.47$ & ${ }^{\star} 20.54 \pm 0.97$ & ${ }^{*} 41.52 \pm 1.83$ & ${ }^{*} 39.49 \pm 1.74$ \\
\hline Mass of leaf dry matter, g & $5.31 \pm 0.22$ & ${ }^{*} 6.17 \pm 0.28$ & ${ }^{\star} 6.02 \pm 0.26$ & ${ }^{\star} 6.13 \pm 0.27$ \\
\hline Specific surface density of the leaf, \\
$\mathrm{mg} / \mathrm{cm}^{2}$
\end{tabular}

Note. ${ }^{*}-P \leq 0.05$. 
The content of starch in the roots decreased in the first half of the vegetative season and increased in the second one, when treatment with growth inhibitors slowed the process of accumulation of polysaccharide (Fig. 1).

Having thoroughly analysed the dynamics of accumulation of sugars in aubergine stems, we state the fact of their accumulation at the beginning of vegetation and their outflow from the axial vegetative organ to the leaves and fruits after the flowering phase, both in the control and in the experiment variants, due to reducing forms (Fig. 1). The use of antigibberellin preparations intensified the outflow of sugars to the leaves and fruits. The amount of starch in stems under the action of tebuconazole during the growing season was less than that in the control variant, and processing by ethephon significantly increased the content of polysaccharide in the stems. We believe that starch accumulation is a negative phenomenon since it inhibits the process of transportation and the transfor- mation of assimilates into economically valuable substances characteristic of this culture.

The study of the dynamics of accumulation and redistribution of sugars and starch in leaves and fruits is highly important in terms of the theory of donor-acceptor relations in a plant (Fig. 1). Having examined the content of sugars in the leaves of aubergines, we state the fact of their accumulation in the first half of the vegetative season and their outflow to the fruits after the end of the flowering phase, both in the control and in the experiment variants due to both the reducing form and sucrose. It was found that the ethylene productent ethephon was not of high importance, and the retardants tebuconazole and chlormequat chloride greatly increased the outflow of sugars from the leaves of experimental plants. The results of our research show that during the vegetative season, the re-utilization of starch from leaves transpieres both in control and in the experiment variants. Antigibberellin preparations intensified this process.

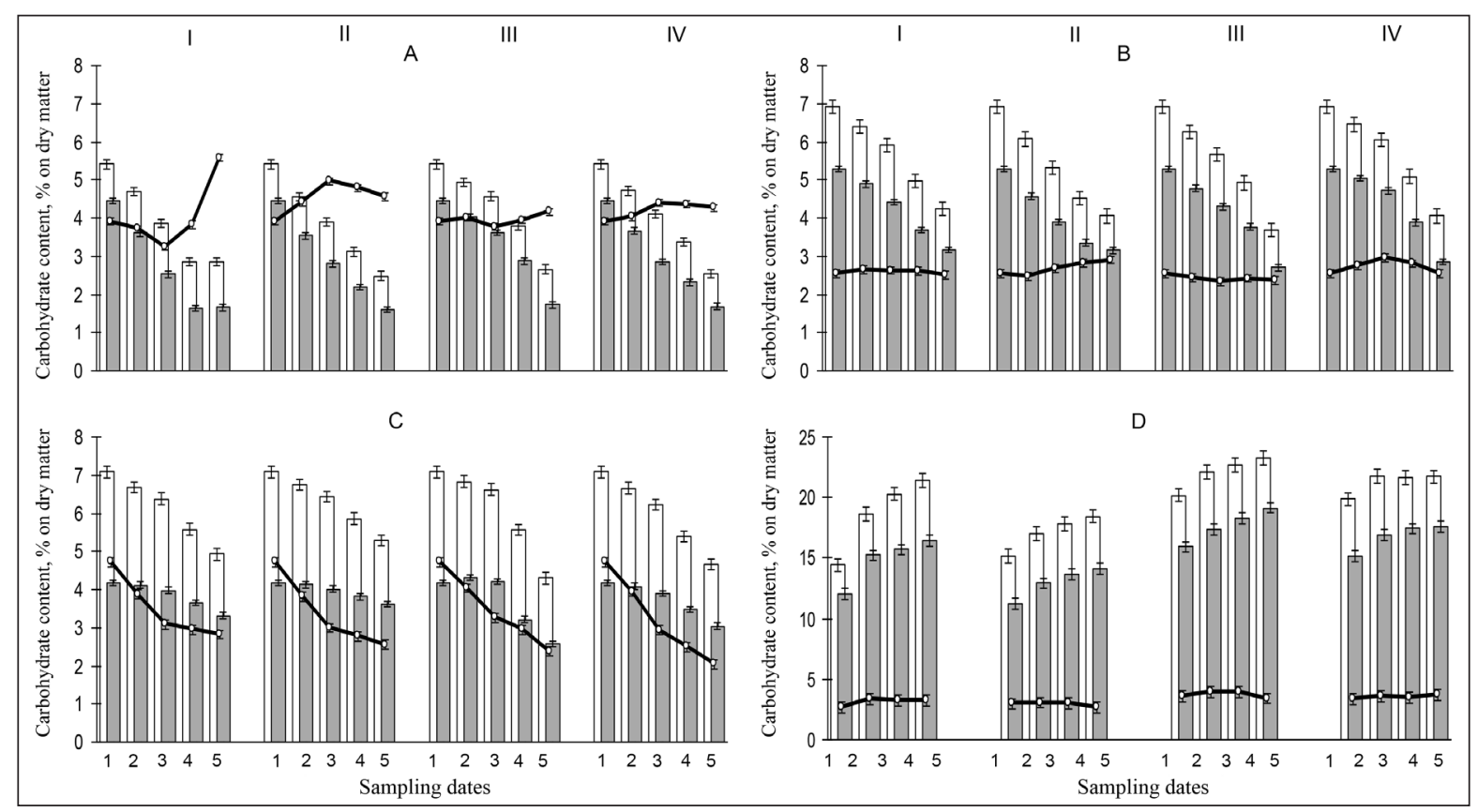

Fig. 1. Influence of growth regulators on the content of various carbohydrate forms in plant organs of aubergines cv. Almaz.

$\square$ - amount of sugar; - $\square$ reducing sugars; - $\longrightarrow$ starch. A - roots; B - stems; C - leaves; D - fruits.

I - control; II - 2-CEPA; III - EW-250; IV - CCC-750 1 - processing date; 2 - day 10 after processing; 3 - day 20 after processing; 4 - day 30 after processing; 5 - day 40 after processing. This is the average data for 2013-2015. 
Having investigated the dynamics of accumulation of various forms of carbohydrates in the fruits of aubergines, we found that during the vegetative season there was an intensive accumulation of these, mainly due to reductive forms of sugars and to a lesser extent due to both sucrose and starch (Fig. 1). Retardants tebuconazole and chlormequat chloride increased the content of sugars in aubergine fruits by $7-40 \%$ and the content of starch by $5-36 \%$. Under the action of ethephon, the amount of sugar in the fruits dropped to $14 \%$, reducing sugars to $15 \%$ and sucrose to $12 \%$ compared to the control variant. The content of starch under the influence of ethylene producent during vegetation decreased by $6-18 \%$.

Increased accumulation of carbohydrates in the aubergine fruits treated with retardants tebuconazole and chlormequat chloride caused an increase in the dry mass of one fruit by $34 \%$ and $47 \%$ respectively. Under the action of ethephon, this indicator decreased by $26 \%$ compared with the control variant (Table 2).

The results of our reasearch indicate that the application of growth inhibitors led to changes in the accumulation and redistribution of various forms of nitrogen (Fig. 2). It was established that the application of retardants tebuconazole and chlormequat chloride increased the outflow of nitrogen from the aubergine roots due to both protein and non-protein forms. At the end of the investigated period, the indicator decreased by $6-18 \%$ compared to the control variant. In the meantime, the growth of all forms of nitrogen in the tissues of the root was observed in all the control variants. Under the action of ethephon, the content of total and protein nitrogen was close to control variants.

Having analysed the dynamics of the accumulation of nitrogen-containing compounds in the aubergine stems, we found that there was a decrease in the content of non-protein forms of nitrogen and the growth of protein nitrogen during vegetation both in control and experiment variants (Fig. 2). After processing with retardants, the process of utilization of both protein and non-protein nitrogen was intensified, and the ethylene producent slowed down the outflow of all forms of nitrogen from the stems.

Investigation of the dynamics of the accumulation of different forms of nitrogen in the aubergine leaves established that treatment with growth and development regulators increased the content of protein nitrogen. The most significant increase in protein nitrogen in the course of vegetation occurred after the use of tebuconazole, and at the end of the research after treatment with the ethephon (Fig. 2).

It was also established that retardants tebuconazole and chlormequat chloride increased the content of protein nitrogen in the leaves of aubergines in the flowering phase and at the beginning of carpogenesis due to the formation of a more powerful photosynthetic apparatus of plants, with the subsequent strengthening of the outflow of proteins to the fruits that are actively formed at this time. This fact was confirmed by the increase in the content of chlorophylls in the leaves of plants treated with

Table 2. Influence of gibberellin inhibitors on productivity of aubergines of cv. "Almaz" (fruit ripening phase, average for 2013-2015, $n=15, \mathrm{x} \pm S D$ )

\begin{tabular}{c|c|c|c|c}
\hline Variant of the experiment & Control variant & 2-CEPA & EW-250 & CCC-750 \\
Indicator & & & & \\
\hline Mass of dry matter of fruits, $g$ & $42.6 \pm 1.96$ & $\star 31.5 \pm 1.51$ & ${ }^{\star} 56.9 \pm 2.69$ & ${ }^{\star} 62.5 \pm 3.03$ \\
\hline Number of fruits per plant, pcs. & $4.04 \pm 0.18$ & ${ }^{\star} 3.58 \pm 0.12$ & ${ }^{\star} 4.66 \pm 0.19$ & $4.27 \pm 0.18$ \\
\hline Average weight of a fruit, g & $136.12 \pm 3.12$ & $142.08 \pm 3.81$ & ${ }^{\star} 150.03 \pm 4.22$ & $145.15 \pm 4.04$ \\
\hline Weight of fruits from one plant, $g$ & $552.13 \pm 26.92$ & $520.07 \pm 24.41$ & ${ }^{\star} 707.14 \pm 32.04$ & $620.18 \pm 30.05$ \\
\hline Fruit yield, $\mathrm{t} / \mathrm{ha}$ & $36.42 \pm 1.06$ & $34.33 \pm 1.33$ & ${ }^{\star} 46.64 \pm 1.22$ & ${ }^{\star} 40.93 \pm 1.21$ \\
\hline
\end{tabular}

Note. $^{*}-P \leq 0.05$. 


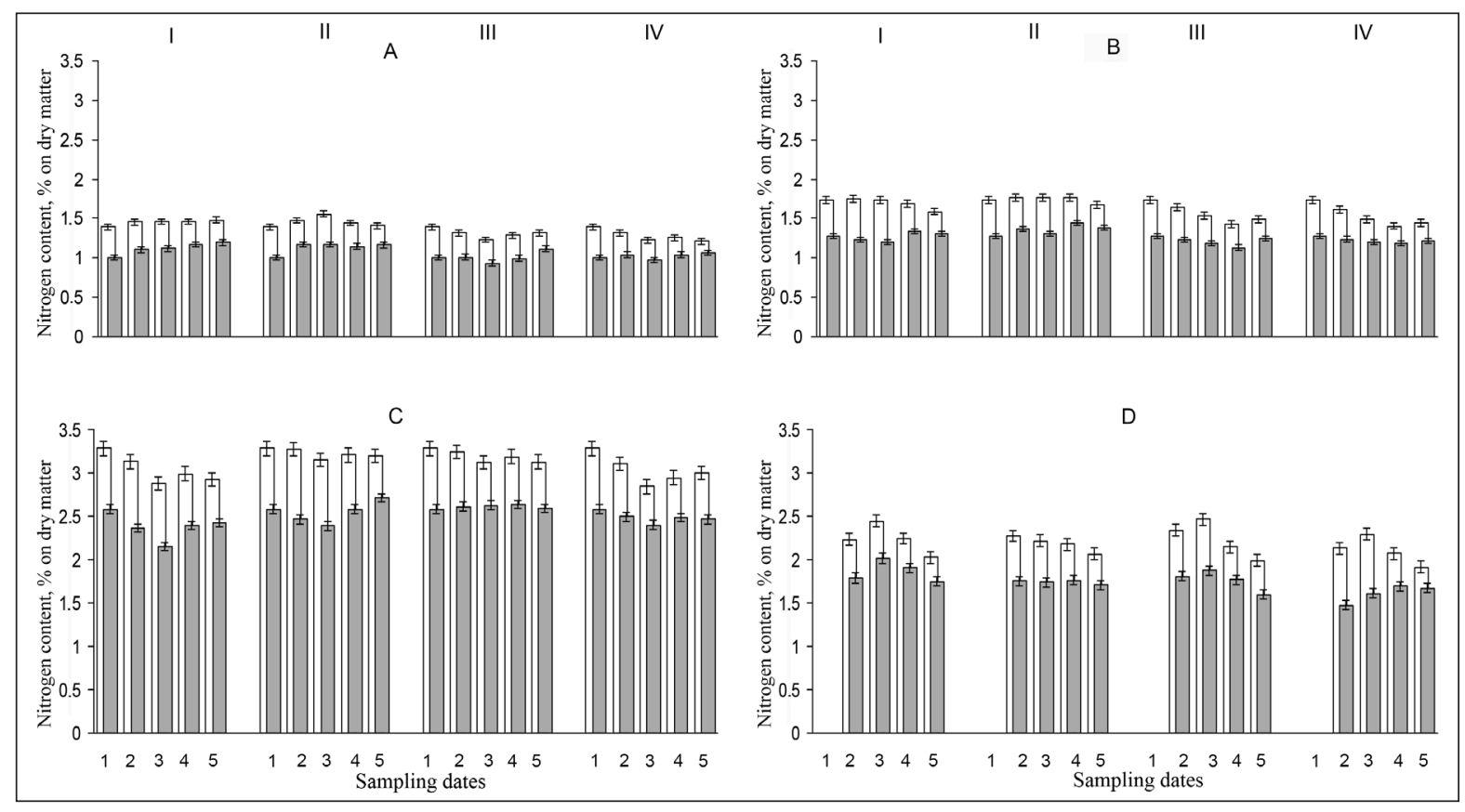

Fig. 2. Influence of growth regulators on the content of various forms of nitrogen in plant organs of aubergines cv. "Almaz".

$\square$ - total nitrogen; - $\square$ protein nitrogen. A - root; B - stems; C - leaves; D - fruits.

I - control; II - 2-CEPA; III - EW-250; IV - CCC-750. 1- processing date; 2 - day 10 after processing; 3 - day 20 after processing; 4 - day 30 after processing; 5 - day 40 after processing. This is the average data for 2013-2015.

preparations and the specific surface density of leaves (see Table 1). After processing with the ethephon, only the processes of the accumulation of protein nitrogen in the leaves were observed (Fig. 2).

After analyzing the dynamics of accumulation and redistribution of different forms of nitrogen during the process of fruit formation, we found that their content, either in control and in the experiment variants, decreased or did not change. After processing of the aubergines with retardants tebuconazole and chlormequat chloride, accumulation of different forms of carbohydrates in the fruits of aubergine resulted in a decrease in the content of protein nitrogen. More vigorously, protein nitrogen was reutilized after using chlormequat chloride. Ethephon practically did not change this indicator in comparison with the control variant (Fig. 2).

The reduction of the protein nitrogen content in the vegetative and generative organs of aubergines under the influence of retardants tebuconazole and chlormequat chloride was accompanied by an enhanced formation of the generative organs. In particular, at the end of the research period, the number of fruits per plant under the influence of retardants increased by $15 \%$ and $5 \%$ respectively.

A gibberellin-inhibitor-induced tendency of an increase in the non-protein forms of nitrogen in the fruits during vegetation was observed.

Consequently, antigibberellin preparations intensified the outflow of sugars from all vegetative organs to the fruits. The main stock polysaccharide form - starch - accumulated only in the roots and stems.

Growth regulators intensified the process of the accumulation of protein form of nitrogen in the leaves, which correlates with the formation of a more powerful photosynthetic apparatus and non-protein forms of nitrogen in the fruits.

Such changes in the accumulation and redistribution of plastic substances in aubergines led 
to an increase in crop productivity. The most effective in this case was the application of tebuconazole. Under its influence, the fruit harvest increased by $28 \%$ compared to the control variant. The treatment with chlormequat chloride resulted in a $12 \%$ increase in the yield. The use of the esphone was ineffective in terms of biological productivity of culture.

\section{DISCUSSION}

It is common knowledge that the regulation of donor-acceptor relations in the system of a whole plant is carried out through the coordination of photosynthesis and the growth function, and any natural or experimental changes in the rate of growth processes are accompanied by an adequate reorganization of the photosynthetic apparatus. The use of the inhibitors of gibberellin allows changes in the growth rates of certain organs of a plant, resulting in a possible redistribution of flows of assimilates to economically important tissues and organs (Kuryata et al., 2016).

Reducing the request for assimilates after the application of retardants and ethylene producers creates the effect of their excess in the plant, which is directed to the increased growth of lateral organs and stocks. The phenomenon of inhibition of growth processes in the axial organs of aubergines recorded by us was accompanied by an increase in the quantitative parameters of the leaf apparatus. Similar effects were observed in sweet potato plants under the influence of poclofurtazole (Yooyongwech et al., 2017), in soybean plants under the action of uniconazole (Yan et al., 2015), and after treatment of perennial ryegrass plants with chlormequat chloride (Kasem, Abd ElBaset, 2015).

The growth of the number of leaves, the mass of their dry matter, and the area of the leaf surface contributes to the increase in photosynthetic productivity of the plant, which simultaneously increases with the decrease of expenses of assimilates on growth processes, followed by redistribution to other tissues and organs of plants. In this regard, it is highly significant to establish the direction of movement of plastic substances in the plant. The results of our research testify to the fact that under the influence of retardants of tebuconazole and chlormequat chloride during the vegetation, the content of sugars and starch in vegetative organs of aubergines constantly decreased, and it increased at the expense of sugars, namely, reducing their forms, in fruits. Such changes in the dynamics are consistent with the general concept of the functioning of the plant organism "source-runoff".

The slowdown of the linear growth by the retardants led to an increase in the content of carbohydrates in the vegetative organs of aubergines compared with control variants. The excess of plastic substances accumulated in the first half of the vegetation under the influence of preparations transported more actively to the fruits. It is with this that we can link the increase in re-utilization of starch in vegetative organs throughout the vegetational period. The growth of carbohydrate content in the vegetative and generative organs of plants under the effects of the retardants was mentioned by other researchers. Paclobutrazole increased the content of sugars in sweet potatoes (Yooyongwech et al., 2017), mangoes (Sarker et al., 2016), rice (Xiang et al., 2017), and canola (Hua et al., 2014). Chlormequat chloride caused a rise in the total content of sugars in perennial ryegrass (Kasem, Abd El-Baset, 2015), sucrose content in lilies (Zheng et al., 2012), and the starch content in potatoes (Koteswara Rao et al., 2017).

The results of our research indicate that the blocking of the formation of the hormonereceptor complex in aubergines under the influence of ethylene producent ethephon had a stronger growth-inhibitory effect than the interruption of the synthesis of gibberellin with tebuconazole. In our opinion, excessive inhibition of growth processes under the effect of the exphasus also caused inhibition of the processes of transporting substances in the plant, which eventually led to the accumulation of assimilates in vegetative organs, while reducing the content of sugars in the fruits, which negatively affected the crop productivity. 
In the meantime, there was a more moderate inhibition of linear growth and transport processes of substances on the plant under the influence of tebuconazole and chlormequat chloride, which created an excess of plastic substances that were actively led to the fruits and participated in the processes of carpogenesis. The formation of an excess of sugars was ensured not only by photosynthetic processes and their lesser use in growth processes, but also as a result of increased hydrolysis of starch in vegetative organs of aubergines under the influence of tebuconazole.

The literature contains information on improving the productivity of crops under the influence of other triazole-based preparations. In particular, the use of paclobutrazol increased the productivity of sweet potato (Yooyongwech et al., 2017), mango (Sarker et al., 2016), canola (Hua et al., 2014), jamun (Hegde et al., 2018), and uniconazol caused the increase in soybean yields (Yan et al., 2015).

It is known that there is a decrease in nitrogen content in vegetative organs due to its outflow to flowers, fruits and seeds, as well as the use of growth processes in the plant as a whole in the process of vegetation. The obtained results allow us to state that the formation of a greater number of fruits under the influence of tebuconazole and chlormequat chloride has led to an increase in the outflow of this element from the roots and stems to the leaves and generative organs. In our opinion, an increase in the content of protein nitrogen in the leaves treated with retardants is a confirmation of a better assimilation of the assimilate donor by an enzyme device, which is considered an additional factor in the activation of photosynthetic processes under the influence of retardants. The reduction of the nitrogen content in the fruits during the vegetative season under the influence of the retardants is obviously due to the biodegradation of the element due to the formation of a larger number of fruits.

Thus, the use of retardants tebuconazole and chlormequat chloride contributed to the formation of the donor sphere of auber- gines, strengthening of their assimilation potential, the temporary deposition of photoassimilates and nitrogen-containing compounds in the vegetative organs of the plant, followed by the active re-utilization of these compounds for the needs of the formation and growth of the fruits. The consequence of such a restructuring of the donor-acceptor system of plants is the increase in the crop of aubergine culture under the actions of this group of preparations. Excessive inhibition of growth and exchange processes in aubergines under the influence of ethylene producent ethephon caused a decrease in the productivity of the culture, despite a number of positive morphometric, physiological, and biochemical effects that manifested themselves after the application of the preparation.

\section{CONCLUSIONS}

The use of an antigibberelin preparation with different mechanisms of action led to changes in growth processes, the leaf apparatus, and the accumulation and redistribution of various forms of carbohydrates and nitrogen in the organs of aubergines cv. "Almaz". Interruption of gibberellin synthesis by tebuconazole and chlormequat chloride inhibited the activity of the apical meristems, which led to a decrease in the linear size of the stem with a simultaneous compensatory increase of lateral and marginal meristems activity. This led to the formation of more leaves, the area growth, and leaf surface density, which indirectly indicates thickening of the leaf plates compared to control. Optimization of the apparatus contributed to the activation of photosynthetic processes, which resulted in increased synthesis of plastic substances. Producing more fruits, the main acceptors of assimilates, under the influence of the retardants increased the outflow of sugars and starch from the vegetative organs, which in turn could further stimulate the donor function of the leaves. Triazole derivatives and onyx inhibitors of gibberellin enhanced the outflow of various nitrogen forms from the roots and the stem with simultaneous growth in 
the leaves due to the protein form, which clearly correlates with the increase in chlorophyll content. The natomic-morphologicaland physiological-biochemical changes mentioned above contributed to the increase in the fruit yield from each plant.

Ethyleneproduct esphon excessively inhibited the growth processes in the aubergine, which adversely affected the biological productivity of the crop.

Received 7 January 2020

Accepted 10 February 2020

\section{References}

1. AOAC official methods of analysis. 18th ed. International Association of Official Analytical Chemists; Gaithersburg, MD, USA: 2010.

2. Golunova LA. Effect of chlormequate chloride on glycine max l. seed productivity and quality. Naukovi zapysky Ternopil's'kogo nacional'nogo pedagogichnogo universytetu. Serija: Biologija. 2015; 1(62): 68-72. Ukrainian.

3. Hegde S, Adiga JD, Honnabyraiah MK, Guruprasad TR, Shivanna M, Halesh GK. Influence of paclobutrazol on growth and yield of jamun cv. Chintamani. Int J Curr Microbiol App Sci. 2018; 7(01): 1590-9.

4. Hua S, Zhang Y, Yu H, Lin B, Ding H, Zhang D, Ren Y, Fang Z. Paclobutrazol application effects on plant height, seed yield and carbohydrate metabolism in canola. Int J Agricult Biol. 2014; 16: 471-9.

5. Kasem MM, Abd El-Baset MM. Studding the Influence of Some Growth Retardants as a Chemical Mower on Ryegrass (Lolium perenne L.). J Plant Sci. 2015; 3(5): 255-8.

6. Kiriziy DA, Stasyk OO, Pryadkina GA, Shadchyna TM. Fotosintez. T. 2. Assimilyatsiya $\mathrm{CO}_{2}$ i mehanizmy jejyo regulyatsii. Logos, Kiev, 2014. Russian.
7. Koteswara Rao G, Surendra Babu M, Nagaraju MM, Thomson T, Ranganna G, Siva M. A critical review on effect of plant growth regulators on root vegetables. International J Curr Microbiol App Sci. 2017; 6(7): 1243-7.

8. Kumbar S, Patil DR, Das KK, Swamy GSK, Thammaiah N, Jayappa J, Gandolkar K. Studies on the influence of growth regulators and chemicals on the quality parameters of grape cv. 2A Clone. Int J Curr Microbiol App Sci. 2017; 6(5): 2585-92.

9. Kuryata VG, Kravets OO. Effect of esfon on growth processes and morphogenesis of tomatoes. Naukovi zapysky Ternopilskoho natsionalnoho pedahohichnoho universytetu. Seriia Biolohiia, 2016; 1(65): 80-5. Ukrainian.

10. Kuryata VG, Khodanitska OO. Peculiarities of morphogenesis and production process of Linum usitatissimum var. humile (Mill.) Pers. plants under the effect of chlormequat-chloride and treptolem. Fiziologiya i biohimiya kul't. rasteniy, 2012; 44(6): 522-8. Ukrainian.

11. Kuryata VG, Polyvanyj SV. Potuzhnist' fotosyntetychnogo aparatu ta nasinnjeva produktyvnist' maku olijnogo za dii' retardantu folikuru. Fyzyologyja rastenyj y genetyka. 2015; 47(4): 313-20. Ukrainian.

12. Kuryata VG, Poprotska IV. The physiological basics of application of retardants to oilseeds. Fiziologiya rasteniy i genetika. 2016; 48(6): 475-87. Ukrainian.

13. Kuryata VG, Rohach VV, Rohach TI, Khranovska TV. The use of antigibberelins with different mechanisms of action on morphogenesis and production process regulation in the plant Solanum melongena (Solanaceae) Visnyk Dnipropetrovs'kogo universytetu. Biologija, ekologija. 2016; 23(2): 221-4.

14. Liu L, Fang Y, Huang M, Jin Y, Sun J, Tao X, Zhang G, He K, Zhao Y, Zhao H. (2014). Uniconazole-induced starch accumulation in the bioenergy crop duckweed (Landoltia punctata) II: transcriptome alterations of pathways 
involved in carbohydrate metabolism and endogenous hormone crosstalk. Biotechnol Biofuels. 2014; 8: 64 .

15. Rogach VV, Poprotska IV, Kuryata VG. Effect of gibberellin and retardants on morphogenesis, photosynthetic apparatus and productivity of the potato. Visnyk of Dnipropetrovsk University. Biology, Ecology. 2016; 24(2): 416-9. Ukrainian.

16. Sardoei AS, Yazdi MR, Shshdadneghad M. Effect of cycocel on growth retardant cycocel on reducing sugar, malondialdehyde and other aldehydes of Cannabis Sativa L. Int J Biosci. 2014; 4(6): 127-33.

17. Sarker BC, Rahim MA, Archbold DD. Combined effects of fertilizer, irrigation, and paclobutrazol on yield and fruit quality of mango. Horticulturae. 2016; 2: 14.

18. Singh SK, Nath V, Marboh ES, Sharma S. Source-sink relationship in litchi verses mango: a concept. Int J Curr Microbiol App Sci. 2017; 6(3): 500-9.

19. Shevchuk OA, Pervachuk MV, Vergelpis VI. Influence of antihypercholine action for the sprouting of been seeds. Bullettin of Uman National University of Horticulture. 2018; 1: 66-71. Ukrainian.

20. Tkachuk OO. Vplyv paklobutrazolu na anatomo-morfologichni pokaznyky roslyn kartopli. Naukovyj visnyk Shidnojevropejs'kogo nacional'nogo universytetu imeni Lesi Ukrai'nky. 2015; 2: 47-50. Ukrainian.

21. Van Emden HF. Statistics for terrified biologists. Blackwell, Oxford, 2008.

22. Wang Y, Gu W, Xie T, Li L, Sun Y, Zhang H, Li J, Wei S. Mixed compound of DCPTA and
CCC increases maize yield by improving plant morphology and upregulating photosynthetic capacity and antioxidants. PLOS ONE. 2016; 11(2): e0149404.

23. Xiang J, Wu H, Zhang Y, Zhang Y, Wang Y, Li Z, Lin H, Chen H, Zhang J, Zhu D. Transcriptomic analysis of gibberellin- and paclobutrazol-treated rice seedlings under submergence. Int J Molec Sci. 2017; 18: 2225.

24. Yan Y, Wan Y, Liu W, Wang X, Yong T, Yang W. Influence of seed treatment with uniconazole powder on soybean growth, photosynthesis, dry matter accumulation after flowering and yield in relay strip intercropping system. Plant Produc Sci. 2015; 18(3): 295-301.

25. Yooyongwech S, Samphumphuang T, Tisarum R, Theerawitaya C, Cha-um S. Waterdeficit tolerance in sweet potato [Ipomoea batatas (L.) Lam.] by foliar application of paclobutrazol: role of soluble sugar and free proline. Front Plant Sci. 2017; 8: 1400.

26. Yu SM, Lo SF, Ho TD. Source-sink communication: regulated by hormone, nutrient, and stress cross-signaling. Trends Plant Sci. 2015; 20(12): 844-57.

27. Zhang W, Xu F, Hua C, Cheng S. Effect of chlorocholine chloride on chlorophyll, photosynthesis, soluble sugar and flavonoids of Ginkgo biloba. Notulae Botanicae Horti Agrobotanici Cluj-Napoca. 2013; 41(1): 97103.

28. Zheng R, Wu Y, Xia Y. Chlorocholine chloride and paclobutrazol treatments promote carbohydrate accumulation in bulbs of Lilium Oriental hybrids "Sorbonne". J Zhejiang Univ Sci B. 2012; 13(2): 136-44. 
Viktor Rogach, Kateryna Reshetnyk, Volodymyr Kuryata, Tatyana Rogach

GIBERELINO INHIBITORIŲ POVEIKIS ĮVAIRIŲ FORMŲ ANGLIAVANDENIŲ IR AZOTO TURINČIŲ JUNGINIŲ KAUPIMUISI IR PERSISKIRSTYMUI SOLANUM MELONGENA L.

\section{Santrauka}

Tebukonazolas 0,025 \% (EW-250), chlormekvato chloridas $0,25 \%$ (CCC-750) ir esfonas 0,15 \% (2CEPA) daro poveiki Solanum melongena L. augimo procesams, lapu formavimuisi, chlorofilo koncentracijai, ịvairiems angliavandenių junginiams bei bendrajam azoto kiekiui. Nustatyta, kad panaudojus šiuos preparatus sumažeja baklažanų matmenys. Ryškiausiai ūgi mažina 2-HEPC. Išvardyti retardantai didina lapų skaičių, lapų sausujų medžiagų masę, lapų plotą, chlorofilų kiekị ir lapų paviršiaus tanki. EW-250 ir CCC-750 retardantai paskatino angliavandenių kaupimąsi baklažanų vaisiuose. Auginimo sezono metu baltyminio azoto kiekis šaknyse ir stiebuose sumažejo tiek kontroliniame, tiek eksperimentiniame variante. EW-250 ir CCC750 pagreitino bendro ir baltyminio azoto nutekejimą iš šaknų ir stiebų, padidino jo kiekị lapuose. Padidindami angliavandenių kiekị vaisiuose, retardantai kartu sumažino ịvairių azoto junginių kiekį. Tebukonazolo poveikis bendro azoto kaitai pagreitino augalo vaisių formavimąsi. Taigi EW-250 ir CCC-750 retardantai pakeite donoro ir akceptoriaus santykį, padidindami medžiagų nutekèjimą iš vegetatyvinių organų $\mathfrak{i}$ vaisius, o kartu ir augalų produktyvumą.

Raktažodžiai: Solanum melongena L., antigiberelino preparatai, cukrus, krakmolas, bendras azotas, produktyvumas 